\title{
Cylindrocladium Root and Petiole Rot of Spathiphyllum spp. New to Taiwan
}

\author{
Yuh-Kun CHEN*, Chang-Hsin KuO** and Lung-Chung CHEN*
}

Key words : Cylindrocladium spathiphylli, root and petiole rot, Spathiphyllum spp.

Spathiphyllum spp., sometimes called peace lilies, are tropical perennial plants belonging to the family Araceae, which are grown for cut flowers and mass plantings in homes and office buildings ${ }^{1,2)}$. Cylindrocladium root and petiole rots ${ }^{2,6)}$ were observed on Spathiphyllum sp. cv. 'Sensation' and an unknown cultivar of Spathiphyllum sp. at Yenpu, Pintung in July 1997. Symptoms, including dark brown to black necrotic lesions with a bright yellow halo, appeared on leaves (Plate I-A) on the lower part of petioles (Plate I-B), along with a severe root rot (Plate I-C). Halochlorosis and petiole epinasty of leaves with necrotic lesion(s) in the basal part of petioles (Plate I-D) were also observed on an unknown cultivar of Spathiphyllum.

Isolates were obtained from the interface between healthy and diseased tissues of both Spathiphyllum sp. cv. 'Sensation' and the unknown cultivar. These leaf, petiole and root sections were dipped into $2 \%$ sodium dichlorite for 3 to $5 \mathrm{~min}$, plated onto $2 \%$ water agar (WA) and observed daily. Cylindrocladium spathiphylli Schoulties. El-Gholl and Alfieri was consistently isolated from these sections. Conidia were picked by a glass needle and spread on fresh WA plates. A single conidium was transferred to potato dextrose agar (PDA) or $10 \%$ V-8 agar. Colonies on PDA and V-8 were initially white and cottony, then turned brown to reddish brown.

Inoculum was prepared by cutting mycelial discs ( 5 $\mathrm{mm}$ in diameter) from $\mathrm{V}-8$ plates. The discs were put onto artificial wounds and intact surfaces of leaves of Spathiphyllum sp. cv. 'Sensation' and the unknown cultivar, respectively. Blank V-8 agar discs were used as controls. The previously described symptoms appeared 2 days later on wounded and 4 days later on unwounded sites, but no symptoms appeared in control treatments. The fungus was reisolated from diseased tissues of inoculated leaves.

Morphological observations of $C$. spathiphylli were made on 4-day-old cultures grown at $25^{\circ} \mathrm{C}$ on Sach's medium $^{4}$ containing a piece of host leaf. Conidia and conidiophores were mounted in a lactophenol mixture. Scanning electron microscopy was also carried out on $C$. spathiphylli cultured on PDA. The samples were fixed with osmium tetroxide vapor at room temperature for
$24 \mathrm{hr}$, then dehydrated with an ethanol series. After critical point dehydration, they were coated with a thin film of gold under high vacuum. A single stipe (sterile appendage) arose from a procumbent mycelial cell and terminated in a capitate, spathulate or ellipsoidal vesicle (Plate II-A). Conidiophores were borne laterally on the stipe and were hyaline, smooth and dichotomously branched. They terminated in two to four cylindrical nonseptate phialides (Plate II-B). The dominant vesicle shape for all C. spathiphylli isolates in this study was capitate (Plate II-C). Spathulate and ellipsoidal vesicles were also commonly seen, and rare bicellular vesicles were also observed (Plate II-D, E, F). The diameters of capitate vesicles were about $12.5-15.5 \mu \mathrm{m}$. Conidia were hyaline, cylindrical, 1-3 septate, $50.0-95.5 \times 5.0-6.5$ $\mu \mathrm{m}$ (ave. $80.5 \times 6.0 \mu \mathrm{m}$ ) (Plate II-G). They were formed singly from the apex of the phialides and grouped in palisade-like clusters (Plate II-A). Most of the conidia were uni-septate $(94.6 \%)$ with the occurrence of biseptate conidia (5\%) and tri-septate conidia (0.4\%). Teleomorphic structures and sclerotial were not observed in diseased tissues and culture plates.

Pathogenicity tests were carried out by separately spraying spore suspensions $\left(1.2 \times 10^{5} \mathrm{spores} / \mathrm{ml}\right)$ or placing mycelial discs (5 $\mathrm{mm}$ in diameter) onto leaves of some araceous plants, including Alocasia $\times$ amazonica hort., Anthurium andraeanum Linden, Anubis barderi, Dieffenbachia picta (Lodd.) Schott 'Rudolph Roehrs', Homalomena rubescens (Roxb.) Kunth 'Emerald Gem', Monstera deliciosa Liebm. Philodendron scandens Koch and Sello subsp. scandens, Rhaphidophora aurens (Lind. ex Andre) Birdsey, Spathiphyllum sp., Spathiphyllum sp. cv. 'Sensation' and Syngonium cv. 'White Butterfly'. Although only Spathiphyllum spp. has been found to be susceptible to C. spathiphylli ${ }^{2)}$, Monstera deliciosa and Philodendron scandens subsp. scandens also showed symptoms 4 days after inoculation with mycelial discs or spore suspensions in this study. Monstera deliciosa showed symptoms similar to that of Spathiphyllum spp., whereas Philodendron scandens subsp. scandens showed water-soaked lesions.

Mycelial growth was tested by placing mycelia on a PDA disc ( $5 \mathrm{~mm}$ in diameter) onto PDA plates and the

\footnotetext{
* Department of Plant Pathology, National Chung Hsing University, Taichung, Taiwan, ROC

** Department of Plant Protection, National Chia-Yi Institute of Technology, Chia-Yi, Taiwan, ROC
} 


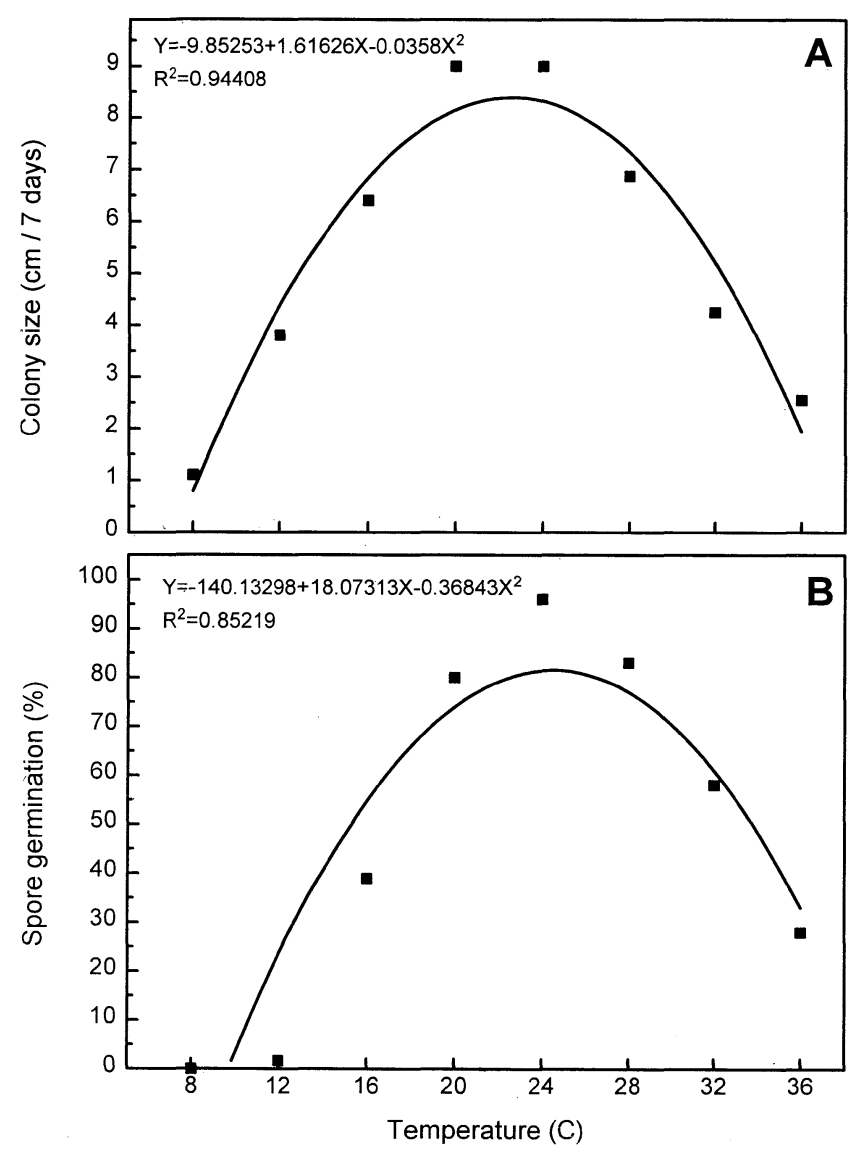

Fig. 1. Effects of temperature on mycelial growth (7 days, A) and germination (6 hr, B) of Cylindrocladium spathiphylli on PDA and WA, respectively.

plates were incubated in incubators at temperatures from 8 to $36^{\circ} \mathrm{C}$. The colonies extended to $90 \mathrm{~mm}$ in diameter in about 7 days at $24^{\circ} \mathrm{C}$. The optimal temperature for mycelial growth was $20-24^{\circ} \mathrm{C}$ (Fig. 1). Conidial germination was tested by spraying spore suspensions on WA plates, then incubating the plates in $8-36^{\circ} \mathrm{C}$ incubators for $6 \mathrm{hr}$. The conidia germinated at $16-36^{\circ} \mathrm{C}$. The optimal temperature for spore germination was $24^{\circ} \mathrm{C}$ (Fig. 1).

Cylindrocladium root and petiole rot of Spathiphyllum spp. was first described in 1980 by Schoulties and ElGholl ${ }^{7)}$ and subsequently discovered in many other areas and countries ${ }^{1,3,9}$. The causal agent was originally identified as $C$. floridanum Sobers and Seymour, then altered to $C$. spathiphylli in 1982, based on size of conidia, mode of stipe formation and shape of vesicles ${ }^{8}$. In the original description of $C$. spathiphylli, the conidia were $80.3 \times 6.0 \mu \mathrm{m}$ in size and presumably all uniseptate, and all vesicles were presumably capitate. However, isolates of C. spathiphylli from Hawaii and Florida in the United States presented different numbers of septa and shapes of vesicles ${ }^{9}$. In those isolates, uni- to 3 -septate conidia and various vesicle shapes were observed. Both conidial and vesicle morphology in this domestic isolate of C. spathiphylli are in conformity with the isolates obtained by Uchida and Aragaki ${ }^{9)}$ and in accordance with the key proposed by Peerally ${ }^{6}$. This is the first report of Cylindrocladium root and petiole rot of Spathiphyllum spp. in Taiwan.

\section{Literature cited}

1. Carrai, C. and Garibaldi, A. (1990). Cylindrocladium spathiphylli agent of root and petiole rot of Spathiphyllum grown for cut flowers. Inf. Fitopatol. 40:41-43.

2. Chase, A.R. (1992). Cylindrocladium root and petiole rot of Spathiphyllum : Compendium of Ornamental Foliage Plant Disease (Chase, A.R. ed.), APS Press, St. Paul, pp. 24-25.

3. Crous, P.W. and Peerally, A. (1996). Gliocladiopsis irregularis sp. nov. and notes on Cylindrocladium spathiphylli. Mycotaxon $58: 119-128$.

4. Dhingra, O.D. and Sinclair, J.B. (1987). Basic Plant Pathology Methods. CRC Press, Boca Raton.

5. Forsberg, L.I. (1988). Cylindrocladium root and petiole rot of Spathiphyllum. Aust. Plant Pathol. $17: 39-40$.

6. Peerally, A. (1991). The classification and phytopathology of Cylindrocladium species. Mycotaxon 40: 323-366.

7. Schoulties, C.L. and El-Gholl, N.E. (1980). Pathogenicity of Cylindrocladium floridanum on Spathiphyllum sp. cv. Clevelandii. Proc. Fla. State Hortic. Soc. $93: 183-186$.

8. Schoulties, C.L. and El-Gholl, N.E. and Alfieri, S.A., Jr. (1982). Cylindrocladium spathiphylli sp. nov. Mycotaxon $16: 265-272$.

9. Uchida, J.Y. and Aragaki, M. (1992). Further characterization of Cylindrocladium spathiphylli from Spathiphyllum in Hawaii and Florida. Mycologia $84: 810-814$.

\section{和 文 摘 要}

陳 煌焜・郭 章信・陳 隆鐘：台湾において初発生のスパシ フィルム (Spathiphyllum spp.) 根腐葉斑病

1997 年 7 月, 台湾屏棟県塩埔町で種名・品種名不詳のスパシ フィルム (Spathiphyllum spp.) および品種緑巨人 (Spathiphyllum sp. cv. 'Sensation') に根腐葉斑病 (root and petiole rot) が発生した。主な病徴は根腐, 葉の褐色壊死病玟, 全葉黄化お よび葉柄下垂で, 罹病組織から Cylindrocladium spathiphylli Schoulties. El-Gholl and Alfieri が分離された。分離菌の菌系 は無色, 菌柄は菌系から単生し, 菌柄先端の頂のうの多くは頭 状でスプーン状ないし棈円形のものもあった。分生子柄は無色, 二叉に分枝し, 分枝先端部に $2 \sim 4$ 個のフィアライドが形成さ れた。分生子は連続的にフィアライドから生じて棚状の束とな り, 無色, 円筒形, 1 3 隔壁のものが多く, 大きさは平均 $80.5 \times$ $6.0 \mu \mathrm{m}$ であった。菌系体は培地上で生育旺盛, 初め白色, 徐々 に菌叢中央から赤褐色に変わった。菌系生長および分生子発芽 の最適温度は $24^{\circ} \mathrm{C}$ であった。台湾における本病の発生の報告は これが最初である。

(Received November 4, 1997 ; Accepted July 2, 1998) 


\section{Plate I}

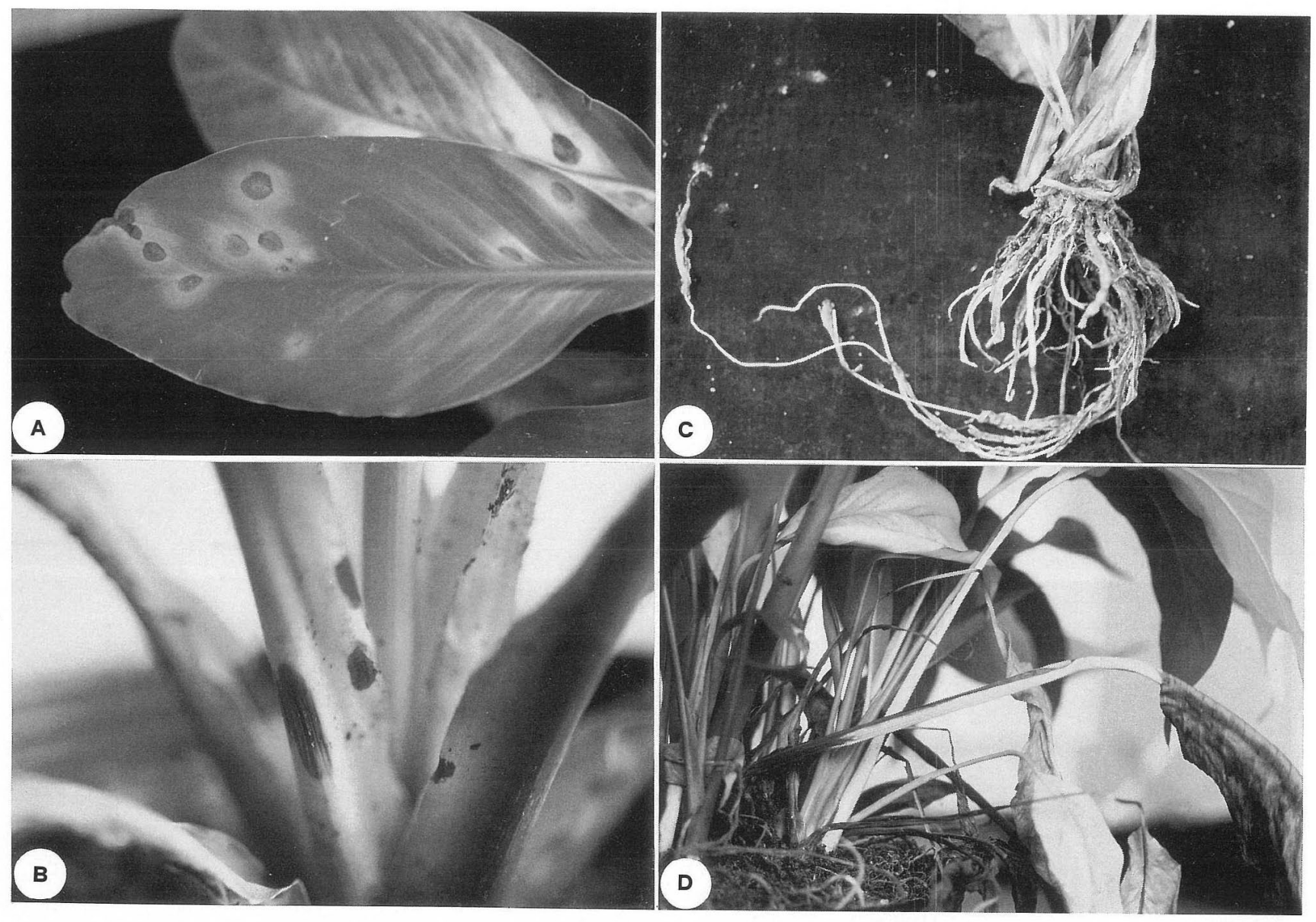

Plate I Symptoms of Cylindrocladium root and petiole rot of Spathiphyllum spp. Naturally infected plants of Spathiphyllum sp. cv. 'Sensation' shows necrotic lesions with yellow halo on leaves (A) and lower part of petiole (B) and severe root rot (C). An infected plant of Spathiphyllum sp. shows chlorotic leaves and epinastic petioles with necrotic lesion(s) in the basal part of petioles (D). 


\section{Plate III}
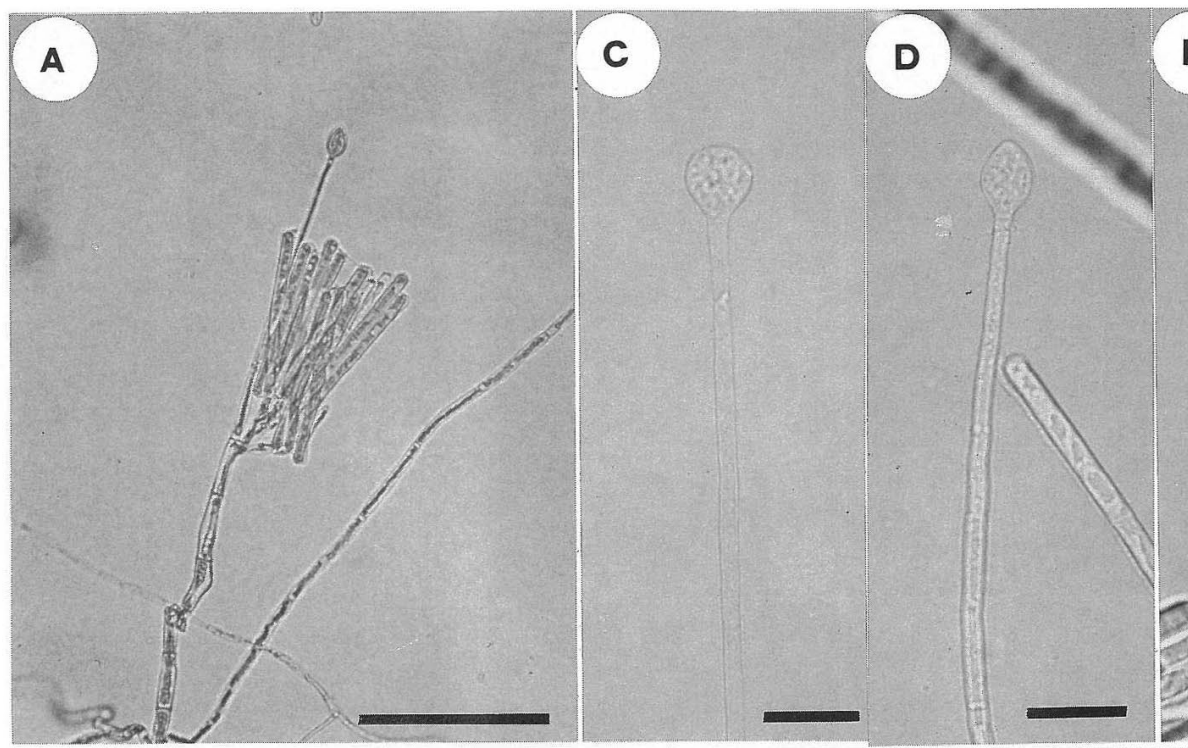

E
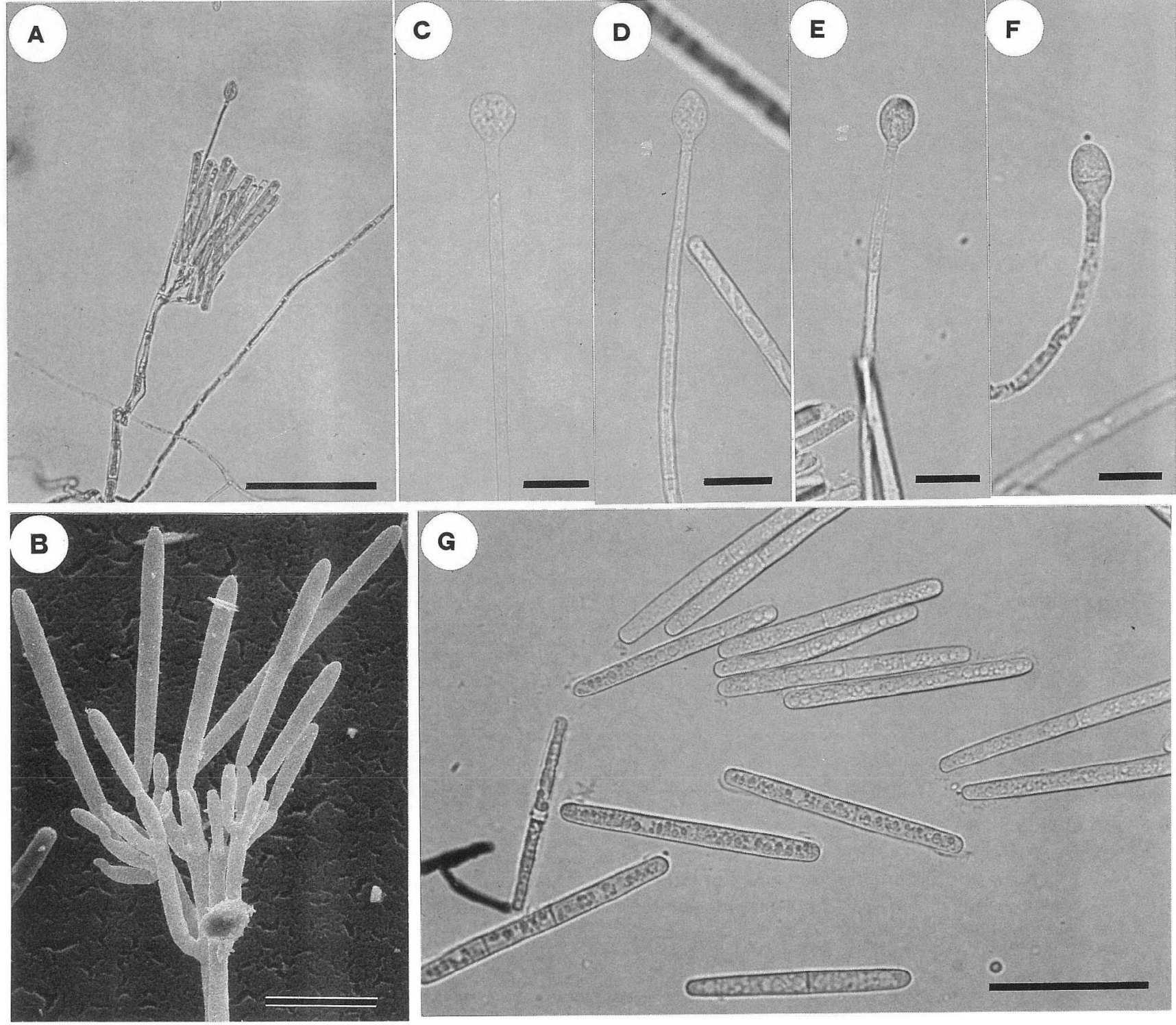

Plate II Microscopic morphology of Cylindrocladium spathiphylli.

A : A single stipe arose from hyphal cell and terminated in a spathulate (A) vesicle. Conidiophores were borne laterally from the stipe and produced conidia in a palisade-like cluster. The bar indicates $100 \mu \mathrm{m}$.

B : Scanning electron micrograph of conidiophores and phialids bearing immature conidia. The bar indicates $20 \mu \mathrm{m}$. C-F : Capitate (C), spathulate (D), ellipsoid (E) and bicellular (F) terminal vesicles of stipe. The bars indicate $20 \mu \mathrm{m}$. G: Uni-, bi-, and tri-septate conidia of C. spathiphylli. The bar indicates $50 \mu \mathrm{m}$. 